\title{
Challenges of Distance, Blended, AND ONLINE LEARNING: A LITERATURE- BASED APPROACH
}

\author{
Godfred Yaw Koi-Akrofi, Emmanuel Owusu-Oware and Hannah Tanye \\ Department of IT Studies, University of Professional Studies, Accra
}

\begin{abstract}
The objectives of the study were to show the basic differences between Distance, Blended and Online learning, and establish their common challenges from literature. Approximately 35 categories/sets of research results or findings from more than 65 publications were reviewed and used for this work. Articles were obtained from sources such as Google Scholar, ResearchGate, Academia.edu, Google Search Engine, and Elsevier. The key themes used for the search are Distance education, Distance learning, Online learning, Blended learning, Differences between face-to-face and online learning, and the use of the internet for learning. The differences between Distance, Blended, and Online Learning (DBOL) modes were summarized, and 11 challenges of DBOL were realized. These 11 challenges were summarized into six themes namely, lack of infrastructure, low or no IT skills, self-disciplinary problems, content issues, policy issues, and social issues. It was strongly advised that, for effective DBOL implementation and operation, there must be in place a solid DBOL policy, adequate infrastructure, and constant training of stakeholders on the use of learning management systems and the development of related IT skills in general.
\end{abstract}

\section{KEYWORDS}

Blended, online, distance, learning, face-to-face, internet.

\section{INTRODUCTION}

Learning on a massive scale such as through Distance Learning (DL) is one of the common efforts that aid development [1]. The current trend of livelihood has necessitated modern education that allows both the working class and students to learn and obtain a university degree through DL. The difficulty of learning is so great in modern times that conventional methods of teaching and learning are not enough to solve it.

Hence, even as technology has helped improve both the quantity and quality of products and services, so must the technology be applied to learning. This is the only way to tackle the learning challenge [2].

The increasing demand for education over the years has led tertiary education providers and regulators to take steps to expand access to meet the rising demand for tertiary education. This has led to an introduction of Distance, Blended, and Online Learning (DBOL) as a new system of education which arises as a result of the increasing number of students who want to further their education to the higher level, the majority of whom are the working class. In sub-Saharan Africa, the ways used to improve accessibility are distance education and franchised campuses [3]. 
International Journal on Integrating Technology in Education (IJITE) Vol.9, No.4, December 2020

Open and distance learning (ODL) has become a central global strategy to overcome the complexities of access to education [4]. Also, Badu-Nyarko [5] quoted Aggor et al. [6] as saying that high costs associated with the country's conventional residential higher education system have rendered higher education beyond the reach of many. For this reason, it is recommended that distance learning (DL) have the potential to contribute to the labor force requirements of any country. In computer technology, the use of an internet network to communicate with other people has provided the opportunity to deliver education to people who are away ([7], [8]).

Distance learning could also be a field of education that focuses on teaching methods and technology to deliver teaching, often on a personal basis, to students who are not physically present during a traditional educational setting like a classroom. DL has been described as "a process to make and supply access to learning when the source of data and therefore the learners are separated by time and distance, or both" [9]. DL is an education system in which teaching and learning actions occur via communication technologies and mailing services by the teachers and students being in a different environment [10]. Alkan [11] defines DL as a pedagogy offered by a variety of environments and teaching units where interactions and communication between planners and practitioners of educational activities and students have been explicitly established under conditions under which conventional teaching and learning methods restrict the use of classroom activities. The basic concept of distance learning considers that the teacher and thus the students are separate within the spatial dimension to which this distance is filled using technical resources [12].

Online learning (OL) transforms education from a teacher-centered (traditional classroom) to a student-centered one, where students are more accountable for their learning ([13],[14]). Online learning is a type of distance learning where technology mediates the learning process, teaching is conducted entirely on the Internet, and students and teachers are not expected to be present at the same time and location.

Delialioglu and Yildirim [15] argued that systematic and strategic incorporation of ICT technologies into academic courses would bring a new approach to teaching objectives. This instructional method has been given many names: blended learning, mediated learning, hybrid instruction, web-assisted instruction, or web-enhanced instruction. Delialioglu and Yildirim [15] and Gülbahar and Madran [16] believed that blended learning is the same as hybrid teaching, which incorporates the ability of web-based training with that of classroom techniques.

For example, Picciano[17] announced that there are two significant elements in describing blended learning and that these are instructions online and face-to-face. Moreover, Rovai and Jordan [18] claimed that blended learning (BL) may be a mixture of online learning and classroom that contain several of the facilities of online courses with the presence of face-to-face communication. Blended learning refers to approaches that incorporate (or combine) conventional face-to-face teaching with online learning.

As distance education has now become a critical tool for the life of most universities in the country, it would be fitting for policy decisions on distance education (DE) to be based on awareness of the inherent and extrinsic problems faced by students [19]. Ohene and Essuman [19] added that investigating the difficulties faced by students would therefore make it possible for DE educators to develop their teaching skills and styles to help ease them, especially in this era of Covid-19, which has necessitated the use of DBOL by most universities. The objectives of the study are therefore to show the basic differences between distance learning, blended (integrated) learning, and online learning, and to recognize or establish their common challenges from literature. 
International Journal on Integrating Technology in Education (IJITE) Vol.9, No.4, December 2020

\section{Materials ANd Methods}

A thorough analysis of the current literature on the challenges of Distance, Blended, and Online learning is conducted. This research deals only with secondary data, primarily from journal articles. Approximately 35 categories/sets of research results or findings from more than 65 publications reviewed are used for this work. No primary data are used for this work. Articles were obtained from sources such as Google Scholar, ResearchGate, Academia.edu, Google Search Engine, Elsevier, etc. The key themes used for the search are Distance education, Distance learning, Online learning, Blended learning, Differences between face-to-face and online learning, The use of the internet for learning, and so on. There were a lot of articles relating to the first three themes than the other themes listed above.

\section{RESULTS}

\subsection{Introduction}

In answering the research question of differentiating between Distance, Blended, and Online learning, the following were the various arguments obtained from literature and summarized later in Table 1.

\subsection{Distance Education}

The United States Distance Learning Association (USDLA) describes distance education as: "A generic, all-inclusive concept used to refer to teachers and learners being physically apart. They further added that information technology is being applied to link teachers and students in different locations. Simonson [20] endorsed this concept from USDLA with the view that "distance education occurs when a teacher and student(s) are physically separated and technology (i.e., speech, video, data or print) is used to bridge the gap in instruction." From the above views, one can deduce that technology brings together learners and their teachers for learning to take place regardless of the distance between them.

According to the National Center for Education (NCE) [21], the terms distance education, online learning, and e-learning are used interchangeably. Distance education uses technology to deliver instruction to students who are separated from the trainer and to support regular and substantive interaction between the students and thus the instructors. The instruction is often delivered synchronously or asynchronously. Another group of researchers also support this concept when defining distance learning as a learning situation in which a student and teacher are physically or geographically separated. Zirkle, Norris, Winegardner, and Frustaci [22] also described DE as the "transmission of instruction from one location to multiple locations through either synchronous or asynchronous telecommunications technology". Distance education is characterized as the planned teaching and learning activities offered within an institutional organization using a communication platform without any time and place limitations [23]. It is well known that distance learning gives learners the advantage of life-long learning thanks to its versatility, but DE comes up with its challenges.

\subsection{Online Learning}

There are many terms for online education. As indicated by Morten F. Paulsen [24], some of them are virtual education, Internet-based education, web-based education, and education via computer-mediated communication. Khan [25], one of the earliest, described online learning as the delivery of instruction to a remote audience using the Internet as an intermediary. Carliner 
International Journal on Integrating Technology in Education (IJITE) Vol.9, No.4, December 2020

[26] described online learning as computer-presented educational content. Both definitions focus on the instruction and the method of delivery.

The Web Education System Project (Web-Edu) uses a concept of online education, cited by Paulsen [24], based on the definition of distance education by Keegan [27]. Online schooling also has the characteristic of:

1. The separation of teachers and learners which distinguishes it from face-to-face education

2. The influence of an academic organization which distinguishes it from self-study and personal tutoring

3. The utilization of a network to present or distribute some educational content

4. The supply of two-way communication via a network so that students may enjoy communication with one another, teachers, and staff

Online learning includes computer-available educational resources, such as online assistance, online documents, and online services. Online learning also includes the office assistant and web page design wizards [28].

As online learning has become more pervasive, the training theories around it have evolved. Most authors ([29], [30], [31], [32]) define online learning in terms of access to learning experiences but also on the potential for flexibility and participant interaction.

\subsection{Blended Learning}

The body of literature on Blended Learning (BL) as cited by Tayebinik and Puteh [33] proves that there is no unity in the definition of blended learning. Again, Driscoll [34] cited by Tayebinik and Puteh [33] defined blended learning as a combination of instructional methods. Delialioglu and Yildirim [15] argued, on the contrary, that the systemic and strategic use of ICT resources in academic courses brings a new approach to educational goals. Several names have been given to this instructional method: mixed learning, facilitated learning, hybrid teaching, web-assisted teaching, or web-enhanced instruction. Delialioglu and Yildirim [15] and Gülbahar and Madran [16] claimed that blended learning is like hybrid coaching, integrating the ability of web-based teaching with that of classroom techniques. Likewise, through their analysis of the transformative potential of mixed learning, Garrison and Kanuka [35] found that mixed learning environments capture conventional class ideals that enhance the efficacy of meaningful learning experiences.

Bonk [36] quoted the three most common concepts of blended learning more conservatively:

1. A mixture of instructional modalities (or delivery media)

2. A combination of instructional methods

3. A combination of online and face-to-face instruction

However, scholars usually accept the third concept. For example, Picciano [17] claimed that there are two essential elements in the concept of blended learning, and those are online and face-toface instructions. Besides, Rovai and Jordan [18] believed that blended learning is a combination of online learning and classroom that includes some of the online course facilities with the presence of face-to-face contact.

Colis and Moonen [37] described blended learning as "a combination of traditional face-to-face and online learning such that teaching takes place both in the classroom and online and where the 
online component becomes a natural extension of traditional learning in the classroom"[37] cited in Rovai\& Jordan [18]).

Blended learning appears to have brought many benefits to the distance education program in raising the obstacles DE faces. In their research, Hameed, Badii, and Cullen [38] found e-learning efficiency when combined with conventional learning: they concluded that the blended learning approach offers the most versatile framework for e-learning. Another advantage of a blended learning environment is its potential to supply many sources for learners.

Azizan[39], cited by Tayebinik and Puteh[33], concluded that the use of technology in physical classrooms provides additional tools for scholars, and this is also expected to enhance the trust and competence of learners and increase the quality of learning. Chen and Jones [40] highlighted other benefits of blended learning, such as a broad understanding of subjects using web-based tools, as well as the active involvement of students in the classroom. Furthermore, online learning engagement provides an interactive setting for communication among teachers and students within the classroom and should facilitate cooperative activities even beyond the school rooms [41].

\subsection{Distance, Blended, and Online Learning (DBOL)}

As stated earlier in the study, DBOL is defined as any form of teaching and learning which occurs substantially outside the traditional (face to face) instructional setting. In the context of this research, once the mode of delivery is not solely face-to-face as in the traditional or conventional method of education, and ICT tools such as the internet, software, learning management systems, and so on are employed, it falls into the definition of DBOL. This definition becomes the operative definition throughout this research; it seeks to put together all the concepts about distance learning, blended learning, and online learning.

With blended learning, you will be able to attend classroom sessions to take advantage of the personal interaction with your teacher from time to time. In a virtual class, you won't be required to enter a classroom. This means that learners can check on their assignments, communicate with instructors, and interact with other students at any time of the day. Students who combine work with studies have the flexibility to do so. When you have a blended education at a junior college, you have got the teacher reminding you of the very fact that projects and assignments are due within a timeframe. Online classes require learners to be extremely disciplined.

In a purely virtual class, you have access to forums and message boards where you can interact with the teacher and the other students. It is not the same as attending classes in person, getting to know your teacher, and interacting with other students in the class. Some students enjoy meeting fellow students and feel this helps in the process of training. They can ask in-person questions which can make their learning easier.

In summary, the position of this paper on the definitions of Distance Education (DE), Online Education $(\mathrm{OE})$, Blended learning $(\mathrm{BL})$, and $\mathrm{DBOL}$ is that:

In DE and OE there is complete separation of student and instructor. In the case of DE, the student learns on his own by employing ICT tools to look out for content on the internet guided by the instructor and/or materials provided by the instructor on a learning management system (LMS), whiles in the case of OE, the student is taught from a remote place using, for example, video conferencing technology, ezTalks Cloud Meeting, and so on, and is also sometimes expected to use the LMS for assignments, learning, etc. 
International Journal on Integrating Technology in Education (IJITE) Vol.9, No.4, December 2020

$\mathrm{BL}$ employs features of $\mathrm{DE}$ and $\mathrm{OE}$ as well as occasional face to face meetings. DBOL is a combination of $\mathrm{DE}, \mathrm{OB}$, and BL which is still substantially different from the traditional face-toface mode of education. From the literature reviewed so far, Table 1 below shows the basic differences between Distance, Blended and Online learning based on specific themes.

Table 1: Differences between Distance, Blended, and Online learning

\begin{tabular}{lllll}
\hline $\begin{array}{l}\text { Learning } \\
\text { mode }\end{array}$ & $\begin{array}{l}\text { Face-to-face } \\
\text { contact }\end{array}$ & $\begin{array}{l}\text { Level of ICT use } \\
\text { (especially, } \\
\text { internet) }\end{array}$ & $\begin{array}{l}\text { Student } \\
\text { involvement }\end{array}$ & $\begin{array}{l}\text { Lecturer } \\
\text { involvement }\end{array}$ \\
\hline Distance & Seldom & high & medium & high \\
\hline Blended & $\begin{array}{l}\text { Often, but far } \\
\text { less than the } \\
\text { traditional } \\
\text { method }\end{array}$ & medium & high & high \\
\hline Online & Not at all & high & high & low \\
\hline
\end{tabular}

\subsection{Findings on challenges of DBOL from Literature}

Table 2 below shows a summary of the findings on challenges of Distance, Blended and Online Learning (DBOL) from the extant literature. A total of 11 (eleven) challenges were identified in the literature reviewed.

Table 2: Findings on Challenges of Distance, Blended and Online Learning (DBOL)

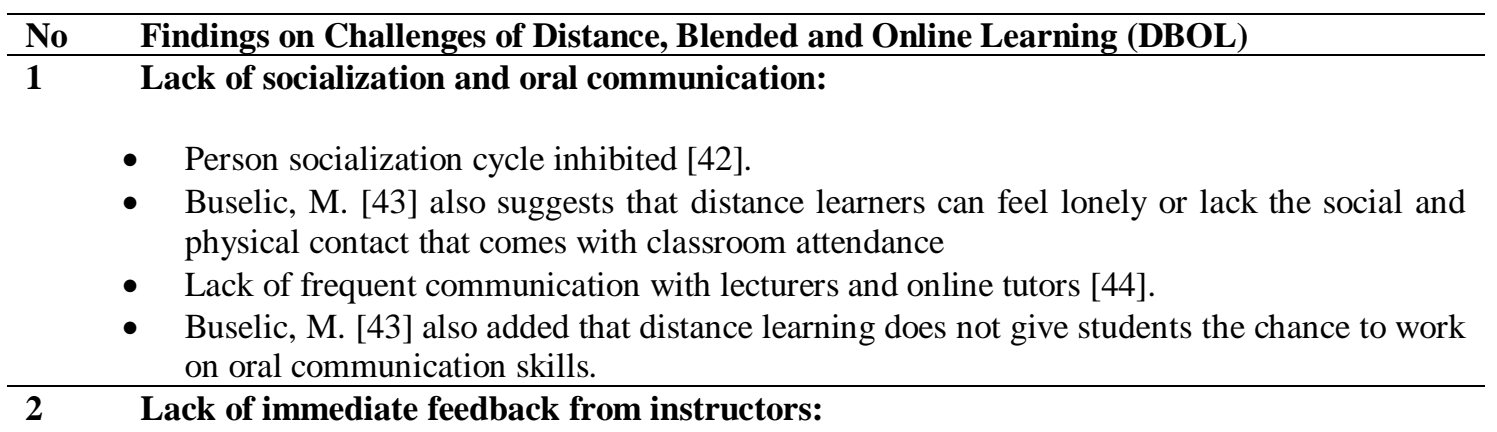

- $\quad$ Distance learning does not have immediate feedback [43].

- Jacobs, P. [45] indicates that online learning produces a condition where the teacher may not be able to offer input readily.

- Lecturers provide constructive feedback to traditional learners and tolerate their inputs in the classroom, and this helps build confidence while distance learners may lack some form of interaction [19]. They also added that feedback on teacher performance is a barrier to distance students.

3 Problem with Appropriateness and Efficacy of DBOL:

- Distance educators still must confront the traditional misconception that distance learning is an inappropriate methodology for the teaching of vocational and technical skills [46].

- Vassiliou and Mcaleese [47] also stated that there is still a widespread view that off-campus or distance learning provision is inferior to the conventional program.

- There are still skeptical attitudes about the full adoption of an e-learning approach in the Student Program ([48], [49]). The social acceptance of Online and Distance Learning (ODL) products is lacking.

4 The problem of access to computers, internet connectivity, and power:

- Most learners have identified power outages and sometimes lack of internet connectivity as 
International Journal on Integrating Technology in Education (IJITE) Vol.9, No.4, December 2020

one of their challenges [50].

- A group of researchers also found that there is a lack of equitable access to Internet tools or resources to make online learning possible in many areas [51].

- Cosmas B. F. Mnyanyi, Jabiri Bakari, and Tolly S. A. Mbwette [52] agree that Internet connectivity challenges, ICT equipment, software, and training are also a problem for DBOL.

- Access to computers is another challenge, the availability of computers and the internet for instructors and students during working hours. For example, in developing countries, most students and instructors will not acquire their computers. The difficulty of accessing computers will negatively affect the acceptance of the technology. It has been reported that unequal access to online learning can lead to inequalities between socioeconomic groups within society [53].

5 Lack of Governmental vision and leadership to develop policies for implementing and providing online learning:

- The inability of Governments to develop policies that will restructure and guide the implementation of the online learning process (Christo Dichev, Darina Dicheva, Gennady Agre \& GaliaAngelova, 2013) [54].

- Vassiliou and McAleese [47] believe that there is a clear lack of comprehensive national elearning strategies in most countries.

6 Lack of Adequate time to study due to the difficulty in creating a balance between studies and other compelling demands:

- $\quad$ Lack of adequate time for study due to their employment responsibilities [44].

- Musingafil, Mapuranga, Chiwanza, and Zebron[55] added that there is a lack of sufficient time to study on the part of DBOL.

- There is limited time for interaction between learners and there is also a short time to complete modules [56].

- The conflict between family, work, and study schedules have been described as one of the major challenges faced by DBOL [55].

- Most DBOL are employees who want to continue their education. For this reason, they need to manage their family and work while continuing their education by creating a balance between work and family or other social responsibilities ([57], [58], [59]). In particular, female learners are reported to be most challenged by family responsibilities such as childcare and domestic work, as well as their work if they are employed [58].

\section{Challenges in Self-discipline and Self-Regulation:}

- Inability to be self-directed and regulate one's own learning in pursuit of academically relevant objectives [60].

8 Inability to cope with the changing environment and modern technology/insufficient Computing skills:

- Many students are used to the traditional "active teacher-passive student" model and it has become a challenge to replace it with e-learning [48].

- Musingafil, Mapuranga, Chiwanza, and Zebron [55] argued that there is a lack of experience and training in teaching technologies of modern learning trends and that it has led to the difficulty of students grappling with this modern learning trend.

- Nor [61] has reported that communication on the Internet is a challenge for adult learners. In another study with online learners by Erickson and Noonan [62], it was reported that the lack of technical skills makes the learning process difficult for learners. The same finding was also reported in the study with students between 41 and 51 years of age, by Dzakiria[63]. He also found that access to reliable information via the Internet is another challenge for adults. The findings of the review showed that older adults who are 50 years of age and older, unlike young and middle-aged adults, have difficulty participating in collaborative activities in a satisfactory manner due to lack of technical skills and lack of internet interaction ([61], [63], [64]). 
International Journal on Integrating Technology in Education (IJITE) Vol.9, No.4, December 2020

9 Financial constraints and lack of support:

- Inadequate funding for institutions to expand and provide access to quality e-learning also affects DBOL [65].

- Limited economic resources in many countries that do not allow investment in the technology infrastructure, content development, and teacher training needed for the implementation of online learning affects DBOL [51]. Lack of working, teaching, and learning materials is one of the challenges facing the Distance Training Program [56].

- Lack of support from family, employer, friends to assist DBOL students tends to be a challenge in their educational process [55].

10 Inability to understand course materials:

- $\quad$ Pierrakeas et al. [66], suggested that DBOL could also be affected by the failure of learners to grasp course materials and their lack of pre-requisite expertise or skills for a course.

11 Lack of teaching and learning materials:

- Lack of working, teaching, and learning materials is one of the challenges facing the Distance Training Programme[56].

A close analysis of the challenges of DBOL in Table 2 presents the challenges in six critical areas or categories discussed below.

Lack of infrastructure: This can be looked at both from the institutional angle (academic institutions) as well as the individual angle (students). Most institutions that are into DBOL lack the requisite infrastructure (Internet access, bandwidth, networks, computers, servers, learning management systems-LMS, and so on) for the effective operation of DBOL. This puts a limitation on the effective operation of DBOL. For instance, if the bandwidth or the internet pipe is not adequate, and the access is not stable, DBOL is usually hampered. The same thing goes for the student who is not adequately resourced in terms of infrastructure (desktop, laptop, smartphone, internet access, and so on) to access the school's infrastructure.

Low or no IT skills (both instructors and students): Lack of requisite IT skills on the part of both instructors and students is a big challenge to effective DBOL. The situation where both instructors and students find it difficult to use an LMS for instance is a major setback to effective DBOL. This is the reason why effective IT and specifically, software training is key from time to time.

Self-disciplinary problems: DBOL requires great discipline as no one is there to monitor the student to learn. The student is required to submit assignments, term papers, case studies, and so on after self-tuition for some time. For those who are not self-disciplined, this mode of learning becomes a big challenge because everything depends on them (purely self-tuition) as against face-to-face learning where colleagues and instructors serve as helpers and encouragers in the learning process.

Content issues: This has two dimensions: lack of content and understanding of the content. In most cases, learning management systems of institutions do not have adequate content necessary for effective learning. Students and lecturers, therefore, resort to other means of getting content, and this sometimes leads to the sourcing of inappropriate content for learning. A vetted and specially prepared content by an institution is reliable and appropriate for learning and is tailored towards the goals of the program. The content must also be concise, straight to the point, free from errors, and explicit. Anything apart from this will pose great challenges to both lecturers and students. 
International Journal on Integrating Technology in Education (IJITE) Vol.9, No.4, December 2020

Policy issues: A policy framework is most of the time lacking for DBOL in most countries. This is made up of a national framework and institutional framework calved from the national framework. The policy framework spells out the quality assurance issues regarding the setup and operation of DBOL centers and institutions. In the absence of this framework, the DBOL product will always be questionable.

Social issues (socialization and acceptance issues): Because DBOL is the direct opposite of face-to-face learning, it removes the element of socialization from it considerably or entirely. This normally hampers the social development of students: relationships, communication, public speaking, healthy and constructive interactions, and so on. Again, for some reason, DBOL is not widely accepted. There is a strong perception of the quality lapses in the process. This makes it unpopular, especially when prospective students have a choice to make between face-to-face and DBOL.

For academic institutions, Covid-19 has ignited a wake-up call throughout the globe of the need to look at DBOL as a strong alternative, and hence the urgency in coming out with DBOL policies, build strong DBOL infrastructure, develop solid content, and train stakeholders on the use of learning management systems and IT skills in general.

\section{Conclusion}

Combining Tables 1 and 2, we can conclude with Table 3 below, showing a matrix on the differences between Distance, Blended, and Online learning using the 11 challenges as criteria.

Table 3: Matrix for DBOL differences

\begin{tabular}{|c|c|c|c|c|}
\hline Item & Criteria & Distance & Blended & Online \\
\hline 1 & Lack of socialization and oral communication & medium & low & high \\
\hline 2 & Lack of immediate feedback from instructors & medium & low & high \\
\hline 3 & $\begin{array}{l}\text { Problem with Appropriateness and Efficacy of } \\
\text { DBOL }\end{array}$ & medium & low & high \\
\hline 4 & $\begin{array}{l}\text { The problem of access to computers, internet } \\
\text { connectivity, and power }\end{array}$ & medium & low & high \\
\hline 5 & $\begin{array}{l}\text { Lack of Governmental vision and leadership to } \\
\text { develop policies for implementing and providing } \\
\text { online learning }\end{array}$ & high & high & high \\
\hline 6 & $\begin{array}{l}\text { Lack of Adequate time to study due to the } \\
\text { difficulty in creating a balance between studies } \\
\text { and other compelling demands }\end{array}$ & high & high & high \\
\hline 7 & $\begin{array}{l}\text { Challenges in } \\
\text { Regulation }\end{array}$ Self-discipline and Self- & medium & low & high \\
\hline 8 & $\begin{array}{l}\text { Inability to cope with the changing environment } \\
\text { and modern technology/insufficient Computing } \\
\text { skills }\end{array}$ & medium & low & high \\
\hline 9 & Financial constraints and lack of support & medium & low & high \\
\hline 10 & Inability to understand course materials & medium & low & high \\
\hline 11 & Lack of teaching and learning materials & high & high & high \\
\hline
\end{tabular}

From Table 3, it can be concluded that Online learning has the most challenges, followed by Distance learning, and then Blended learning. This is because blended learning is the closest to face-to-face learning. Online learning can be assumed to be the direct opposite of face-to-face learning. Distance is more tilted to Online learning than to face-to-face learning. 
International Journal on Integrating Technology in Education (IJITE) Vol.9, No.4, December 2020

\section{REFERENCES}

[1] Bakia, M.; Shear, L.; Toyama, Y.; Lasseter, A. Understanding the implications of online learning for educational productivity. U.S. Department of Education Office of Educational Technology. 2012.

[2] Daniel, J.; Mallet, J. The contribution of ICT to development. The Commonwealth of Learning Experience. Distances and Knowledge. 2008, 6(2): 297-310.

[3] Larkai, T. A. Distance Learning in Ghana - Employing Innovation to Combat Accessibility. Poster Presentation, Going Global, May 2014, Miami.

[4] UNESCO. Education for All: The Quality Imperative. EFA Global Monitoring Report. UNESCO: Paris. 2004.

[5] Badu-Nyarko, S.K. Faculty attitudes towards participation in University based distance education in Ghana. Journal of Literacy and Adult Education. 2000, Vol. 2, No. 1 P.31-41.

[6] Aggor, R. A.; Kinyanjui, P.E.; Pecku, N. K.; Yerbury, J.C. Survey on Distance Education in Ghana. A Report for the Deputy Secretary Higher Education .MOE Ghana. COL. 1992.

[7] Varol, N. “ønternet'inUzaktanE $\div$ itimdekiKonumu”. 2007. http://scholar.google.com

[8] Tuncay, N.; Uzunboylu, H. Anxiety and Resistance in Distance Learning. Cypriot Journal of Educational Sciences. 2010, 5(2), 142- 150

[9] Honeyman, M.; Miller, G. Agriculture distance education: A valid alternative for higher education? Proceedings of the 20th Annual National Agricultural Education Research Meeting. 1993, 67 - 73.

[10] Slater, M. Implicit Learning Through Embodiment in Immersive Virtual Reality. In: Liu D., Dede C., Huang R., Richards J. (eds) Virtual, Augmented, and Mixed Realities in Education. Smart Computing and Intelligence. Springer, Singapore. 2017. https://doi.org/10.1007/978-981-10-5490-7_2

[11] Alkan, C. E-itimTeknolojisi. AnÕYayÕncÕOÕ̂k: Ankara. 1998.

[12] Casarotti, M.; Filipponi, L.; Pieti, L.; Sartori, R. Educational interaction in distance learning: Analysis of a one-way video and two-way audio system. PsychNology Journal. 2002, Volume 1, Number 1, 28 $-38$

[13] Lee, K. The nursing educator's role in e-learning: A literature review. Nurse education today. 2014. 34. 10.1016/j.ned

[14] Peterson, D. S. A meta-analytic study of adult self-directed learning and online nursing education: A review of research from 1995 to 2007. 2008. Retrieved from http://search.proquest.com.proxy.lib.sfu.ca/ docview/194001867?accountid=13800

[15] Delialioglu, O.; Yildirim Z. Students' perceptions on effective dimensions of Interactive learning in a blended learning environment. Journal of Educational Technology \& Society. 2007, 10(2), 133-146. Retrieved from http://www.ifets.info/journals/10_2/12.pdf

[16] Gülbahar, Y.; Madran R. O. Communication and collaboration, satisfaction, equity, and autonomy in blended learning environments: A case from Turkey. International Review of Research in Open and Distance Learning. 2009, 10(2): 1-22.

[17] Picciano, A. G. Blended Learning Implication for growth and access. Journal of asynchronous learning networks. 2006,10 (3).

[18] Rovai, A.P; Jordan, H.P. Blended Learning and Sense of Community: A comparative analysis with traditional and fully online graduate courses. International Review of Research in Open and Distance Learning. 2004, 5 (2).

[19] Ohene, J.B.; Essuman, S.O. Challenges Faced by Distance Education Students of the University of Education, Winneba: Implications for Strategic Planning. Journal of Education and Training. ISSN 2330-9709, 2014, (2). Retrieved from www.macrothink.org/jet156

[20] Simonson, I. Regarding inherent preferences. Journal of Consumer Psychology. 2008, 18, $191-196$.

[21] National Center for Education Statistics. 2019-20 Survey Materials: Glossary. 2019. Retrieved from https://surveys.nces.ed.gov/ipeds/Downloads/Forms/IPEDSGlossary.pdf

[22] Zirkle, C.; Norris, C.; Colerain, W.; Frustaci, E. Distance Education Programming Barriers in Business Education Teacher Preparation Programs in the United States. Career and Technical Education Research. 2006, 31(2), pp.101-118

[23] Moore, M. G.; Kearsley, G. Distance education: A systems view of online learning. Cengage Learning. 2011.

[24] Paulsen, M. F. Online Education Systems: Discussion and Definition of Terms. 2002. http://home.nettskolen.com/ morten NKI Distance Education

[25] Khan, B. Web-based instruction: What is it and why is it? In B. H. Khan (Ed.), Web-based instruction (pp. 5-18). Englewood Cliffs, NJ: Educational Technology Publications.1997. 
International Journal on Integrating Technology in Education (IJITE) Vol.9, No.4, December 2020

[26] Carliner, S. Overview of online learning. Amherst, MA: Human Resource Development Press. 1999.

[27] Keegan, D. Concepts: Problems in defining the field of distance education. American Journal of Distance Education. 1998, 2:2, 4 11, DOI: 10.1080/08923648809526619

[28] Tavukcu, T. et al. General Overview on Distance Education Concept. Procedia Social and Behavioral Sciences. 2011, 15, 3999-4004. Retrieved from www.sciencedirect.com

[29] Benson, A.D. Using Online Learning To Meet Workforce Demand: A Case Study of Stakeholder Influence. Quarterly Review of Distance Education. 2002, 3(4), 443. Retrieved November 1, 2020 from https://www.learntechlib.org/p/95258/.

[30] Carliner, S. An overview of online learning (2nd Ed.). Armherst, MA: Human Resource Development Press. 2004.

[31] Conrad, D. Building and Maintaining Community in Cohort-Based Online Learning. International Journal of E-learning and Distance Education. 2002, Vol. 20 No. 1 (2005)

[32] Ally, M. Designing effective learning objects for distance education. In R. McGreal (Ed.), Online Education Using Learning Objects. 2004a, (pp. 87-97). London: RoutledgeFalmer.

[33] Tayebinik, M.; Puteh, M. Blended Learning or E-learning? International Magazine on Advances in Computer Science and Telecommunications. 2012, 3(1), 103-110.

[34] Driscoll, M. Blended learning: Let's get beyond e-learning. 2002. Retrieved from: http://www.ltimagazine.com

[35] Garrison, D.R.; Kanuka, H. Blended learning: Uncovering its transformative potential in higher education. Internet and Higher Education. 2004, 7, 95-105.

[36] Bonk, C. J. Online Teaching in an Online World (executive summary). USDLA Journal. 2001, Vol. 16, No. 1.

[37] Collis, B.; Moonen, J. Flexible Learning in a Digital World: Experiences and Expectations. London: Kogan Page. 2001.

[38] Hameed, S.; Badii, A.; Cullen, A. J. Effective e-learning integration with traditional learning in a blended learning environment. European and Mediterranean conference on information system. 2008.

[39] Azizan, F.Z. Blended Learning in Higher Education Institution in Malaysia. Proceedings of Regional Conference on Knowledge Integration in ICT. 2010.

[40] Chen, C.C.; Jones, K.T. Blended learning vs. traditional classroom settings: Assessing effectiveness and student perceptions in an MBA accounting course. The Journal of Educators Online. 2007, 4(1), 1-15

[41] Yuen, C. Y. M. Dimensions of diversity: Challenges to secondary school teachers with implications for intercultural teacher education. Teaching and Teacher Education. 2010, 26, 732-741. doi:10.1016/j.tate.2009.10.009

[42] Tayebinik, M.; Puteh, M. Challenges in supporting self-regulation in distance education environments. Journal of Computing in Higher Education. 2011, 23(2), 104-123.

[43] Bušelić, M. Distance Learning - concepts and contributions. OeconomicaJadertina. 2012, 2 (10), 15291/oec.209

[44] Budiman, R. Distance language learning: students' views of challenges and solutions. International Journal on New Trends in Education and Their Implications. 2015, 6 (3): 14 ISSN 1309-6249.

[45] Jacobs, P. The Challenges of Online Courses for the Instructor. Research in Higher Education Journal. 2013, 21, 1-18.

[46] Burns, M.. Distance Education for Teacher Training: Modes, Models and Methods. 2011.

[47] Vassiliou, A.; Mcaleese, M. New modes of learning and teaching in higher education. Luxembourg: Publications Office of the European Union. 2014, 1-37, doi:10.2766/81897.

[48] Santession, I.L.; Elf, M. How to achieve quality in practice-oriented education in an e-learning context. 2012.

[49] Biao, I. Open and Distance Learning: Achievements and Challenges in a Developing SubEducational Sector in Africa. 2012. DOI: 10.5772/48080.

[50] Wakahiu, J.; Kangethe, S. Efficacy Of Online Distance Learning: Lessons from the Higher Education for Sisters in Africa program. European Journal of Research and Reflection in Educational Sciences. 2014, 2 (1).

[51] Dichev, C.; Dicheva, D.; Agre, G.; Angelova, G. Current Practices, Trends and Challenges in K-12 Online Learning. 2013.

[52] Cosmas B. F. M.; Jabiri, B.; Tolly S. A. M. Implementing E-learning in Higher Open and Distance Learning Institutions in Developing Countries: The Experience of The Open University of Tanzania. The Open University of Tanzania. 2010. 
International Journal on Integrating Technology in Education (IJITE) Vol.9, No.4, December 2020

[53] Petrus, V. M. The Good, the Bad, and the Ugly of Distance Learning in Higher Education, Trends in E-learning, Mahmut Sinecen, IntechOpen. 2018. DOI: 10.5772/intechopen.75702. Available from: https://www.intechopen.com/books/trends-in-e-learning/the-good-the-bad-and-the-ugly-of-distancelearning-in-higher-education

[54] Dichev, C.; Dicheva, D.; Angelova, G.; Agre, G. From Gamification to Gameful Design and Gameful Experience in Learning. Cybernetics and information technologies. 2013, Volume 14, No 4. DOI: 10.1515/cait-2014-0007

[55] usingafi, M. C. C.; Mapuranga, B.; Chiwanza, K.; Zebron, S. Challenges for Open and Distance learning (ODL) Students: Experiences from Students of the Zimbabwe Open University. Journal of Education and Practice. 2015, 6 (18), 59-66.

[56] Ndayambaje, I.; Bimenyaimana, T.; Ndahayo, V. A Study on Practices and Challenges of Distance Training Programme (DTP) under Kigali Institute of Education (KIE). Rwanda Journal of Education.2013.

[57] Doherty, W. An analysis of multiple factors affecting retention in Web-based community college courses. The Internet and Higher Education. 2006, 9(4), 245-255. https://doi.org/10.1016/j. iheduc.2006.08.004

[58] Selwyn, N. Finding an appropriate fit for me: examining the (in) flexibilities of international distance learning. International Journal of Lifelong Education. 2011, 30(3), 367-383. https://doi.org/ 10.1080/02601370.2011.570873

[59] Yasmin, D. Application of the classification tree model in predicting learner dropout behaviour in open and distance learning. Distance Education. 2013, 34(2), 218-231. https://doi.org/10.1080/015 87919.2013.793642

[60] Bol, L.; Garner, J. K. Challenges in supporting self-regulation in distance education environments. J Comput High Educ. 2011, 23:104-123 DOI 10.1007/s12528-011-9046-7

[61] Nor, N. M. M. Understanding older adult learners in distance education: The case of UniversitiSains Malaysia. Turkish Online Journal of Distance Education. 2011, 12(3), 229-340. Retrieved from http://dergipark.gov.tr/tojde/issue/16905/176282

[62] Erickson, A. S. G.; Noonan, P. M. Late-career adults in online education: A rewarding experience for individuals aged 50 to 65. MERLOT Journal of Online Learning and Teaching. 2010, 6(2), 388-397. Retrieved from http://jolt.merlot.org/vol6no2/erickson_0610.pdf

[63] Dzakiria, H. Illuminating the Importance of Lsearning Interaction to Open Distance Learning (ODL) Success: A Qualitative Perspectives of Adult Learners in Perlis, Malaysia. European Journal of Open, Distance and E-Learning. 2012. Retrieved from http://www.eurodl.org/materials/contrib/2012/Dzakiria.pdf

[64] Chang, B.; Kang, H. Challenges facing group work online. Distance Education. 2016, 37(1), $73-88$. https://doi.org/10.1080/01587919.2016.1154781

[65] Sife, A. S.; Lwoga, E.T.; Sanga, C. New technologies for teaching and learning: Challenges for Higher Learning Institutions in Developing Countries. International Journal of Education and Development using Information and Communication Technology (IJEDICT). 2007, 3 (2), 57-67.

[66] Pierrakeas, C.; Xeno, M.; Panagiotakopoulos, C.; Vergidis, D. A comparative study of dropout rates and causes for two different distance education courses. The International Review of Research in Open and Distributed Learning. 2004, 5(2), 1-15. https://doi.org/10.19173/ irrodl.v5i2.183 
International Journal on Integrating Technology in Education (IJITE) Vol.9, No.4, December 2020

\section{AUTHORS}

Godfred Yaw Koi-Akrofi is a senior lecturer and HOD for the Information Technology Studies Department of the University of Professional Studies, Accra in Ghana. He has Ph.D. in Management- Information Systems Management (ISM) from Universidad Central de Nicaragua (UCN), MBA in Management Information Systems (MIS) from University of Ghana Business School (UGBS), University of Ghana, Accra, Ghana, and Bachelor of Science (B.Sc.) in Electrical/Electronic Engineering, Kwame Nkrumah University of Science and Technology (KNUST), Kumasi, Ghana. He has worked with multinationals such as British Telecom, AT \& T, MCI Communications Corp., Sprint

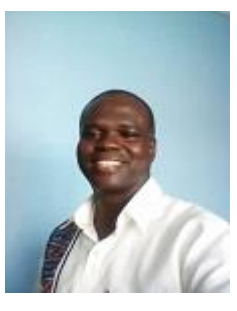
Corporation, Verizon Communications, Deutsche Telekom, KPN, Orange, Telenor ASA, and so on as a Telecom engineer/Manager and Interconnect (Technical, Sales and Accounting) Manager with Ghana Telecom/Vodafone Ghana/Huawei Technologies for over 10 years. He has 12 years of experience as a lecturer in Tertiary education. He has 20 peer-reviewed journal articles, three books, and three conference papers. Areas of Research are in IT/IS Management, Telecommunications, MIS and the organization, Organizational Behaviour, and Management, Business Organizational Dynamics, Post-Merger/Acquisition Dynamics in the Telecoms and IT sectors, Quality Management, IS/IT/Business Strategy, IT/IS Project Management/ IT Design and Systems Thinking, IT investments and organizational performance, Complementary assets and value creation beyond IT investments.

Emmanuel Owusu-Oware is a senior lecturer and Acting Vice Dean for the Faculty of Information Technology and Communications Studies at the University of Professional Studies, Accra. He has his Ph.D. in Information Systems from the University of Ghana. His research interests are public-sector biometric systems and generally digital innovations in organizations. His research has been published in the Information Systems Management Journal, Information Technology for Development Journal, as well as International Conference Proceedings and Book Chapters.

Hannah has a $\mathrm{PhD}$ in Information Systems. Hannah Ayaba Tanye is a lecturer at the Faculty of IT \& Communication Studies at University of Professional Studies, Accra. Hannah Ayaba Tanye has several publications and her research interest areas are eLearning, distance learning, and learning technologies.
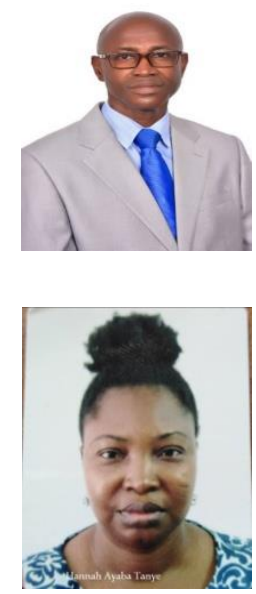